\title{
DESIGNING CURRICULUM, CAPACITY OF INNOVATION, AND PERFORMANCES: A Study on the Pesantrens in North Sumatra
}

\author{
Jafar Syahbuddin Ritonga \\ Sekolah Tinggi Ilmu Ekonomi Harapan \\ Jl. Imam Bonjol No. 35, Medan, Sumatera Utara, 20152 \\ e-mail: jsr_jasari@yahoo.com
}

\begin{abstract}
Abstrak: Sebenarnya cukup banyak artikel dan studi tentang pesantren yang telah dipublikasikan secara meluas. Hampir semua dari literatur tersebut adalah mendiskusikan tentang pesantren dari perspektif Islam (keagamaan) semata. Artikel ini mencoba menawarkan suatu perspektif baru dalam bidang pesantren, yaitu sebagai suatu entitas bisnis. Artikel berbasis riset ini bertujuan untuk mengetahui bagaimana prestasi kerja suatu pesantren yang dipengaruhi oleh (kegiatan) mendeisain kurikulum pada tingkat kapasitas inovasi yang berbeda-beda. Data akan dianalisa dengan menggunakan metode stastikal deskriptif dan inferensial melalui frekuensi, regresi berganda, dan regresi bertingkat. Pada akhirnya, hipotesa dan kesimpulan akan diajukan. Artikel ini menunjukkan pengaruh dari aktivitas merancang kurikulum yang modern dan islami dari suatu pesantren dengan prestasi kerja yang diharapkan akan berbeda-beda sesuai dengan tingkat kapasitas inovasi yang ada di dalam pesantren tersebut.
\end{abstract}

\begin{abstract}
Desain Kurikulum, Kemampuan Inovasi dan Performa: Studi Pesantren di Sumatera Utara. There have been many articles and studies on Pesantren that have been published. Unfortunately, Almost all of them discuss about the Pesantren from the perspective of Islam exclusively. This paper tries to offer a new perspective in looking at the Pesantren: as an entity of business. This is a research paper which aims to know how Pesantrens' performances are influenced by designing curriculum at different levels of capacity of innovation. The data are analyzed using descriptive and inferential statistics, namely frequency, multiple regressions and hierarchical regression. This paper analyzes the influence of designing the curriculum on performances of the Pesantren and the important effects of capacity of innovation on them. This paper reveals that the influence of designing modern Islamic currciculum to the Pesantren's performances is expected to be varied according to the levels of capacity of innovation at the Pesantren.
\end{abstract}

Keywords: pesantren, social entrepreneurship, curriculum, innovation 


\section{Introduction}

A Pesantren is an Islamic educational organization with a boarding system, where Kyai (leader) functions as the centreal figure, Masjid (mosque) functions as the centre of activities, with studying of Islamic knowledge by Santris (students) under the guidance of the Kyai as the main activity. ${ }^{1}$ In the history of education In Indonesia, the Pesantren is the oldest Islamic form of educational institution. ${ }^{2}$ For the beginning, the social mission of a Pesantren is to disseminate and deepen Islamic doctrines through Islamic educational activities. $^{3}$

The Pesantren cannot be substituted in an effective way by any other educational institution because of its unique characteristics. Due to development its functions: not only as an educational institution, but the Pesantren also has broadened its roles as a social organization. As time progress not only as an educational institution, but the Pesantren functions also as a social and Islamic dissemination organization. ${ }^{4}$ However, the Pesantren has become more and more marginalized over the time. It cannot compete with the secular schools and other modern education institutions that existing today. In North Sumatera, a growing number of Pesantrens has been closed in the last few years because of their poor performances. ${ }^{5}$

These phenomena of the Pesantrens can be explained by Theory of Social Entrepreneurship (SE). The Pesantren, arguably as a form of SEs, will capitalize on designing the curriculumas a strategic activity- to improve its performances; 'strategic' means relating to identification of long-term and overall aims or interests of the Pesantren. Further informed by Contingency theory, the influence of designing the curriculum to the Pesantren's performances is expected to be varied according to the levels of capacity of innovation exists at the Pesantren. The theory of Contingency always attempts to relate many variables and is actually used to identify and measure the situations under which things are likely to happen.

\section{Theory of Social Entrepreneurship}

The term of Social Entrepreneurship (SE) has become an important phenomenon in economic and business on a global scale. This is due to the difficulties of separating the business and social functions of an activity. SE was introduced to address the issues of social

${ }^{1}$ Imam Zarkasyi, founder of Pesantren Gontor.

${ }^{2}$ C.A. Brooks, Social Entrepreneurship a Modern Approach to Social Value Creation (New Jersey, USA: Prentice Hall, 2009), h. 23.

${ }^{3}$ Ibid.

${ }^{4}$ Mastuhu, Dinamika Sistem Pendidikan Pesantren: Suatu Kajian tentang Unsur dan Nilai Sistem Pendidikan Pesantren (Jakarta: INIS, 1994), h. 12.

${ }^{5}$ For the case in North Sumatera based on data from Ministry of Religious Affair of North Sumatera and field observation. 
problems in the 1970's. The term of 'social entrepreneur' was first mentioned in 1972 by Joseph Banks in his seminal work, 'The Sociology of Social Movements', where he used that term to describe the need to use managerial skills to address social problems, as well as to address business challenges. SE practices emerged in the 1980s with the establishment of Ashoka, the first organization in the world to support social entrepreneurs. ${ }^{6}$

In general, SE means the activities of an entrepreneur to meet social needs. According to Austin (2006), SE is entrepreneurial activity with an embedded social purpose. SE is used to overcome social problems, as Bornstein (2004) states that this is where social opportunities emerge for SE. ${ }^{7}$ It is an effective way of solving the inabilities of the public sector to meet changing and growing social needs. SE is establishing a prioritization of the social issues above the economic ones. ${ }^{8}$ It broadly describes ventures that strive to create social value rather than placing their priority on generating superior profit. In SE, social value creation appears to be the primary objective, while economic value creation is often a by-product that allows the organization to achieve sustainability and selfsufficiency. SE activities can be done in several forms of venture. According to Mair \& Marti (2004), whether social entrepreneurs choose a non-profit or for-profit vehicle depends on the particular business model and the specific social need addressed.

Another significant factor that clearly differentiates between social and business entrepreneurs is their motivation. The interest of social entrepreneurs stems from their role in addressing critical social problems and the dedication they show in improving the well-being of society ${ }^{9}$. Social entrepreneurs carry out their social activities on an entirely voluntary basis or, as Levie and Hart (2011) state, in 'the spirit of their activity'. The essence of SE is voluntary innovation and a kind of friendship with a combination of goodwill ${ }^{10}$. Besides that, the public often holds social entrepreneurs in high regard because of the multitude of social needs they satisfy and the improved quality they bring to affected societies ${ }^{11}$.

${ }^{6}$ R. E. Ebrashi, "Social Entrepreneurship Theory and Sustainable Social Impact," in Social Responsibility Journal, Vol. 9, No. 2, p. 188-209; E. Sundin, Entrepreneurship and Social Community Care. Journal of Enterprising Communities: People and Places in the Global Economy (n.p.p.: n.p., 2011).

${ }^{7}$ D. Bornstein \& Davis S, Social Entrepreneurship: What Everyone Needs to Know. (Oxford, UK: University Press, 2010), p. 28; P. Tapsell and C.A. Woods, Spiral of Innovation Framework for Social Entrepreneurship: Social Innovation at the Gernerational Divide in an Indigenous Contex, Emergence: Complexity \& Organization (n.p.p.: n.p., 2008).

${ }^{8}$ A. Nicholls, "The Legitimacy of Social Enterpreneurship: Reflexive Isomorphism in a Pre-Pradigmatic Field," in Entrepreneurship Theory \& Practice, Vol. 34, 4, 2010, p. 1042-2587.

9S.A. Zahra, et al. "A Typology of Social Entrepreneurs: Motives, Search Processes and Ethical Challenges," in Journal of Business Venturing, 24, p. 519-532.

${ }^{10}$ Salarzehi, et al., "Waqf as a Social Entrepreneurship Model in Islam," in International Journal of Business and Management, Vol. 5, No. 7, July 2010.

${ }^{11}$ S. Abu-Saifan, Social Entrepreneurship: Definition and Boundaries, Technology Innovation Management Review, Ed. February 2012. 


\section{Designing Curriculum}

Curriculum is a core element in the education system of any educational institution. Curriculum consists of the formal and informal content and processes by which learners gain knowledge and understanding, develop skills and attitudes, appreciations and values under the auspices of an academic institution. According to Hamalik (2007), curriculum is all the activities that are organized to affect the learning processes. A curriculum specifies the general and specific goals that a school wants to achieve.

Designing the curriculum can be defined as a process of selecting and organizing the formal and informal contents of teaching-learning programs at a school, including at a Pesantren. Therefore, designing the curriculum has a direct influence on the performances or outcomes of the santris of the Pesantren. According to Nasution (2006), one of the important components of a formal educational institution that is used as a standard to decide the content of the learning program is the quality of the education process; a success indicator of educational quality is the curriculum.

Nowadays, society is questioning the curriculum and the education system of the Pesantren in general. This is due to the poor academic performances of the Pesantren's santris and alumni. The education system of a traditional Pesantrenis only able to produce one single Ulama from 100 santris; the remaining 99 santris are merely contributors to purchase oil to prepare meals ${ }^{12}$.

Due to the poor quality of its educational outcomes, the Pesantren has to reform and re design its curriculum. The Pesantren requires modern Islamic curriculum in order to improve its performance. This new modern curriculum must be still based onthe strength of Islamic knowledge, but have a strong relevance to the needs of a modern world, both in the present and future. According to Madjid (2008), in facing the internal challenges, the Pesantren must prioritize on curriculum change; a reformation of curriculum is a requirement for the Pesantrens in order to adjust to globalization and modernization; however, it will be an interesting challenge for the Pesantren to respond to all the changes happening outside the Pesantren without losing its strong identity.

The Ministry of Religious Affairs has also acknowledged this situation. Nowadays, the Pesantren cannot offer a competitive educational model that is able to produce santris who are proficient at mastering general knowledge and skills, at the same time having the strength to compete in a social life that is constantly being accelerated by change as a consequence of modernization and the developments in science and technology (Departemen Agama RI, 2004).

${ }^{12}$ M. Yunus, "Social Business Entrepreneurs are the Solution," in Nicholls A. (ed.), Social Entrepreneurship: New Models of Sustainable Social Change (Oxford: Oxford University Press, 2008), p. 39-44. 
In fact, students from boarding schools like the Pesantrenwill possibly achieve higher academic performances than those from non-boarding schools. This is due to the potential strengths of a boarding school's curriculum, which is slightly different from those of nonboarding schools because of the nature of boarding schools. Rebbeca Garland (2013), an education expert, mentions that the curriculum at boarding schools is much more stringent and challenging than that at public or even most private schools, and, as the students are able to dedicate more time to their studies without the distractions of home life; the expectations for these children are greater. Boarding schools, like many private schools, are not bogged down with the Governmental regulations that control state schools, and are able to teach much more than the state's minimum curriculum.

Eventhough the Government gives some directions for its curriculum, due to its strong independence, as mentioned by Rahim (2001) the Pesantren is relatively free and has the chance to develop its owncurriculum and education system. According to Ahmadi (2011), the Pesantren can specialize in the mastery of practical knowledge through the application of technology, so the applied curriculum should not be too academic, and thus the Pesantren, as a basis of Islamic strength, has strong relevance to the needs of a modern world, both now and in the future.

Besides guiding the performance of the santris, curriculum design will affect surplus or deficit of funds from the Pesantren and the percentage of santris from non-local areas. If no renewal of methodology is udertaken, the Pesantren will be abandoned by the community (El-Chumaedy, 2002). It means that the Islamic community will discard the Pesantrens, which have still maintained the status-quo of their old and traditional curriculum, as its main choice of educational institution for the Moslem children.

\section{Capacity of Innovation}

Generally Social Entrepreneurship (SE) means a way of handling social needs that have been unmet. In taking care of the unmet social needs, SE must be innovative in order to deliver the solutions of the social needs better. One factor that makes social entrepreneurs distinct from other forms of entrepreneur is: Social entrepreneurs act within organizations that are oriented towards entrepreneurship, and which have a strong culture of innovation and openness ${ }^{13}$. While it is possible to be a successful entrepreneur without being innovative, social entrepreneurs almost always use innovative methods: they innovate new welfare services and new ways of delivering existing services. An organization's capacity to innovate can be thought of as the potential of that organization to generate innovative output. ${ }^{14}$ According

${ }^{13}$ S. Abu-Saifan, Social Entrepreneurship, p. 123.

${ }^{14} \mathrm{~A}$. Neely, and J. Hii, "The Innovative Capacity of Firms," in Nang Yan Business Journal, Vol. 1-1, pp. 1-07. 
to Drucker (1985), innovation is the process through which something new and/or different is created.

The Pesantren, like the other forms of SE, needs innovation in order to perform better. To achieve success, the Pesantren must have basic capital, that is, a willingness to innovate and be flexible, because the passage of time, progress and the challenges of modernization will present it with an opportunity to innovate. Innovation in the Pesantren world will not only be applied in the context of the learning process, but it also includes all aspects of the Pesantren. In other words, innovation includes the hardware and software of the Pesantren. Information and Communication Technology (ICT) is a sample of creative innovations at a Pesantren. E-learning methods have many advantages for a Pesantren. Each student can study anytime and anywhere, without needing to be with the teacher. The student has an option to choose the subjects that he/she wants to study. This technology can be called "e-Pesantren". The benefits of this e-Pesantren are not only for the santris, but also for the Kyais and Ustadzs.

In actual facts, Islam always puts high respects on good change, innovation and invention because it facilitates people's lives. The world of the Pesantren has introduced a popular principle, "al-muhafadzatu 'ala qadim al-salih wa al-akhdu bi al-jadid al-ashlah", which means: maintaining the good classic culture and always looking for new, better and constructive culture. The freedom to change to new ways is a must, as long as it does not move outside the framework of "ashlah" (being better). If the world of the Pesantren is required to make a change as a consequence of modernization, the aspect of "Ashlah" is a key factor that must be taken into consideration.

\section{Performances of Pesantren}

An organization must use performance indicators to measure or evaluate the value it makes or the success of a particular activity in which it is engaged. Choosing the appropriate performance indicators for an organization will depend much on a good understanding of something that is important and significant for that organization. However, due to the specific and unique characteristics of an organization, sometimes specific and non-common indicators must be created. Measuring social effects is harder and more difficult than measuring business returns. This is due to the forms and circumstances of the social effects. SE's projects are established to address complex problems and, for many, their outcomes are likely to be uncertain. Besides that, social benefits are often intangible, hard to quantify, difficult to attribute to the single organization, best evaluated in the future and open to dispute.

Due to the unique characteristics and conditions of the Pesantren, the specific indicators that function as the success measurements of a Pesantren must be chosen to differentiate it from other SEs or educational institutions. There are three indicators that can be used to measure performances of the Pesantren, both as their outcomes and impacts: 


\section{Santris' Academic Achievements (SAA)}

The most important criterion for "qualifying" as a social venture is establishing the organization to create a certain social impact and measuring the success of the organization based on the achievement of the social impact. ${ }^{15}$ SEs should not focus on outputs, rather on service provision, and creating sustainable change. For social entrepreneurs, the ultimate result of the social enterprise is to create sustainable change in the lives of people, and this change should be on a community level rather than on an individual level: social impacts rather than outcomes. ${ }^{16}$ However, SEs also have clear outcomes that lead to social impacts, which define the organization's success; the outcomes and social impacts of the social ventures together differentiate social ventures from business ventures. ${ }^{17}$ Social impact and social change are the sensible outcomes produced by social enterprises.

One of the main indicators to measure performances of the Pesantren is academic performance of the santris. Academic performance is an outcome of the education process: the extent to which a student has achieved his/her educational goals. Academic performance of the santris is a clear outcome of a Pesantren that can lead to social impacts.

\section{Surplus or Deficit of Funds from Operations (SFO)}

What distinguishes SE from commercial entrepreneurship is a predominant focus on value creation as opposed to value capture. ${ }^{18}$ However, the value creation of a SE, which is a consequence of its social missions, must be balanced by value capture from its operations in order to ensure its sustainability. Social mission organizations usually maximize value creation and satisfy value capture by aiming to capture just enough value to sustain operations and re-invest in growth. According to Dees \& Anderson, the benefits of combining social purpose with enterprise have been found to include greater market responsiveness, efficiency, innovation, and leveraging of resources. Social enterprises aim to achieve financial sustainability by combining financial, physical and human resources. The financial resources might be derived from market sources (revenue from the sale of goods and services), nonmarket sources (Government grants and program funding, independent grants, donations and philanthropy), and non-monitory resources (volunteer labor and social capital).

The objective of SE is to deliver the intended social value while remaining financially self-sufficient, reducing the reliance on donations and Government funding, and increasing the potential for expanding the delivery of the proposed social value. SE is purely not-forprofit and about creating a "surplus" to maintain organization sustainability. Even, SE is

\footnotetext{
${ }^{15}$ Ebrashi, Entrepreneurship Theory and Sustainable Social Impact," p. 188-209.

${ }^{16}$ Ibid.

${ }^{17}$ Ibid.

${ }^{18}$ F.M. Santos, "A Positive Theory of Social Entrepreneurship," in Journal of Business Ethics, Vol. 111, 2012, p. 335-351.
} 
allowed to create profit from its activities. Profit that comes from earned incomes is crucial for social entrepreneurs to sustain their ventures. However, social enterprises are prevented from distributing profits to those who exercise control over them. Any surplus must be retained in the organization and/or community, either as direct services or as grants to the service-targeted population. For the Pesantren and the other forms of SE, generating surplus of fund from its operation is very important to maintain their sustainability.

\section{Percentage of Santris From Non-Local Areas (SNL)}

Activities of SE are usually started as potential solutions to overcome small social problems in the local area. However, in order to be sustainable social entrepreneurs must try to create wider social impacts. The innovative solution that social entrepreneurs validate in their local context often gets replicated in other places and can end up being a global industry ${ }^{19}$. Aravind Eye Hospital, esatblished in 1976 by Dr. Venkataswamy in India, is a sample of successful SEs by widening its covered patients and areas. It has offered eyecare services and cataract surgery to cure blindness at a very small fraction of the usual cost of such services. Aravind has suceeded in making a profit and performs 220,000 eye operations per year. The effect of the hospital's existence to the community is astonishing: $85 \%$ of male and $60 \%$ of female patients, who had lost their jobs as a result of blindness, regained their jobs after surgery. The activities of Aravind have catalyzed social transformation not only in India but also in wider areas, such as: Nepal, Egypt, Malawi, Kenya, Guatemala, El Salvador, and other countries where the initiative has been replicated.

In general, a Pesantren is started in the local context to educate Moslem children in the surrounding (local) areas. Most Pesantrens are situated in remote urban areas; the santris only come from the surrounding areas, close to the Pesantren. If the community can accept the Pesantren's existence due to its educational quality, system, and other related factors, its santris will come not only from the surrounding (local) areas, but also from far (non-local areas); so the bigger the percentage, the more successful the Pesantren.

\section{Research Framework and Measurement}

Based on the theories of Contingency and Social Entrepreneurship (SE), the conceptualization of the factors can be developed. The concept is quantified into: Dependent Variable (DV) is the performances of the Pesantren, consist of: Santris' Academic Achievements, Surplus or Deficit of Funds from Operations, and Percentage of Santris from Non-Local Areas; Independent Variable (IV) is Designing the Curriculum Design, and Moderating Variable (MV) is Capacity of Innovation. Theory of Contingency shows a relationship between two phenomena: firstly, Designing Curriculum with Performances of Pesantren and secondly,

${ }^{19}$ Zahra, et al., "A Typology of Social Entrepreneurs," p. 519-532. 
Capacity of Innovation with the relationship between Designing Curriculum and Performances of Pesantren. The Capacity of Innovation is expected to give more positive effects on the relationship between Designing Curriculum and Performances of Pesantren.

Based on the above research framework, there are six hypotheses that can be formed: H1: Designing modern Islamic curriculum will produce high santris' academic achievements. H2: Designing modern Islamic curriculum the curriculum will generate surplus of funds from operation. H3: Designing modern Islamic curriculum will attract a large percentage of santris from non-local areas. H4: When capacity of innovation is high, designing modern Islamic curriculum will produce higher santris' academic achievements. H5: When capacity of innovation is high, designing modern Islamic curriculum will generate greater surplus of funds from operation. H6: When capacity of innovation is high, designing modern Islamic curriculum will attract larger percentage of santris from non-local areas.

The variable of santris' academic achievements (SAA) is measured by qualitative comparisons of several general subjects that are similarly taught at all types of Pesantren and the secular schools and examined in the National Test, such as: Indonesian Language, Math and Science. This is due to differences in typology of the Pesantren: Khalafiyah (modern) and Salafiyah (traditional) that have caused differences in academic performance indicators of the santris.

There are two indicators that can be used to measure variable of surplus or deficit of funds from its operations (SFO): Fund availability to cover its routine operational costs, such as staff salaries and electricity costs, and Availability of surplus of funds to pay for non-routine operational costs, for instance building facilities and buying new educational equipment. To measure the variable of the Pesantren's performances is by percentage of its santris from non-local areas (SNL), which measured by distance above 100 kilometres from the Pesantren itself.

The variable of designing the curriculum asks about modern Islamic curriculum. The components of designing the modern Islamic curriculum are taken from statement of Madjid (2008): the new curriculum must be still a basis of Islamic strength, but have strong relevance to the needs of the modern world, both in the present and in the future. This is strengthened by Departemen Agama (2004) which states that nowadays the Pesantren can offer a competitive education model that is able to produce santris who have high competence in mastering general knowledge and skills and at the same time have the strength to compete in the social life. To measure this variable, there are three indicators used: Capability of the applied curriculum to develop "akhlâq al-karîmah" (good traits) in the santris, Capability of the applied curriculum to prepare the santris to fulfill the needs of the modern world: at the present and the future, and Capability of the applied curriculum to help the santris in mastering general knowledge and skills.

Capacity of Innovation is depicted as the potential of that organization to generate 
innovative output ${ }^{20}$. The questions which developed to measure dimension of the Pesantren's capacity of innovation are "the capacity of Innovation of an organization is dependent upon the resources and capabilities that it possesses, as these allow it to explore and exploit opportunities." 21 There are four questions related to it: Support from the Kyai, as Top Manager, in doing the innovation; Having commitment of employees toward continuous improvement of the Pesantren; Availability of resources needed for doing innovation, such as: budgets, tools, rewards, and other things, and Capability in capturing and generating new ideas for innovation, both from internal and external environments.

\section{Methodology}

This study has used a graphic rating with ten-point scale to measure the variables, rangin from 1 (worst), 5 (adequate), and 10 (excellent). As a consequence of using selfadapted and developed questions, two colleagues were asked to help editing contents of the questions. Valid questions should be prepared based on rational and empirical facts. Opinions and views were asked from the Pesantren-related experts to validate the questionnaire. If using a standardized questionnaire it will not necessary to test the validity, but for the unstandardized questionnaire, a test of validity should be performed to avoid any bias.

Before distributing the questionnaire to the respondents, a pretest and pilot study were conducted. According to Podsakoff, the pretest was aimed to avoid vaque concepts and keep the questions as easy and concise as possible. The pre-test had asked for definition of concepts to be determined by the prospective respondents or persons who have the same characteristics with the respondents. The target audience of this pre-test was chosen from few Ustadzs (teachers of Pesantren) and middle-up managers of Pesantren Darul Mursyid (PDM), as representatives of the Ustadzs and the Kyais (leaders of Pesantren) in this study. There were several feedbacks that had been collected from the target audience which are very useful to improve the measuring instruments of this study.

The pilot study had been made after conducting the pre-test, which aims to measure the validity and reliability of the questionnaire. The questionnaire of this study was tested to 50 respondents that have the same characteristics as the targeted respondents: highly reliable and valid variables were achieved for each of the variables. According to Kerlinger (1973), the validity and reliability of items asked in the questionnaire can be determined by using factor analysis and reliability tests.

Data of this study were collected on the basis of a population of 190 Pesantrens operating in the 2012/2013 academic-year. Finally, data from 172 Pesantrens were used where a Pesantren, as one unit of analysis, was represented by two respondents: the Kyai and the Ustadz. They

\footnotetext{
${ }^{20}$ Neely, and Hii, “The Innovative Capacity of Firms," pp. 1-07.

${ }^{21}$ Ibid.
} 
MIQOT Vol. XL No. 1 Januari-Juni 2016

are the main actors who are central to the Pesantren's operation. The average from two complete responses, from the Kyai and the Ustadz, became a Pesantren's response.

\section{Analysis, Result, and Discussion}

The study analyzed the hypothesized model by using descriptive and inferential statistics, namely frequency, multiple regressions and hierarchical regression.

Table 1:

Moderating Effect of Capacity of Innovation (CoI) on Relationships between Designing Modern Islamic Curriculum (DMIC) and Santris' Academic Achievements (SAA)

\begin{tabular}{|c|c|c|c|c|c|c|}
\hline & \multicolumn{2}{|c|}{ Model 1} & \multicolumn{2}{|c|}{ Model 2} & \multicolumn{2}{|c|}{ Model 3} \\
\hline & Std. Beta & t values & Std. Beta & t values & Std. Beta & $\mathrm{t}$ values \\
\hline $\begin{array}{l}\text { Step } 1 \text { - Predictor } \\
\text { Variables(DMIC) }\end{array}$ & .216 & $3.965 *$ & .183 & $3.400 *$ & -.018 & -.297 \\
\hline $\begin{array}{l}\text { Step } 2 \text { - Moderating } \\
\text { Variable(CoI) }\end{array}$ & & & .210 & $3.349^{*}$ & -.802 & -5.615 \\
\hline $\begin{array}{l}\text { Step } 3 \text { - Interaction } \\
\text { (DMIC x CoI) }\end{array}$ & & & & & .742 & $4.840^{*}$ \\
\hline
\end{tabular}

Note:*sig. at $p<.05$

Table 2:

Moderating Effect of Capacity of Innovation (CoI) on the Relationships between Designing Modern Islamic Curriculum (DMIC) and Surplus of Funds from Operation (SFO)

\begin{tabular}{|c|c|c|c|c|c|c|}
\hline & \multicolumn{2}{|c|}{ Model 1} & \multicolumn{2}{|c|}{ Model 2} & \multicolumn{2}{|c|}{ Model 3} \\
\hline & Std. Beta & $\mathrm{t}$ values & Std. Beta & Std. Beta & $\mathrm{t}$ values & Std. Beta \\
\hline $\begin{array}{l}\text { Step } 1 \text { - Predictor } \\
\text { Variables (DMIC) }\end{array}$ & .133 & $1.734^{*}$ & .096 & 1.247 & -.022 & -.217 \\
\hline $\begin{array}{l}\text { Step } 2 \text { - Moderating } \\
\text { Variable (CoI) }\end{array}$ & & & .238 & $2.661 *$ & -.850 & -3.559 \\
\hline $\begin{array}{l}\text { Step } 3 \text { - Interaction } \\
\text { (DMIC x CoI) }\end{array}$ & & & & & .377 & 1.314 \\
\hline
\end{tabular}

Note: *sig. at $p<.05$ 
Table 3:

Moderating Effect of Capacity of Innovation (CoI) on the Relationships between Designing Modern Islamic Curriculum (DMIC) and Percentage of Santris from Non-Local Areas (SNL)

\begin{tabular}{|c|c|c|c|c|c|c|}
\hline & \multicolumn{2}{|c|}{ Model 1} & \multicolumn{2}{|c|}{ Model 2} & \multicolumn{2}{|c|}{ Model 3} \\
\hline & Std. Beta & $\mathrm{t}$ values & Std. Beta & Std. Beta & $\mathrm{t}$ values & Std. Beta \\
\hline $\begin{array}{l}\text { Step } 1 \text { - Predictor } \\
\text { Variables (DMIC) }\end{array}$ & .791 & $2.008 *$ & .723 & 1.132 & .336 & .623 \\
\hline $\begin{array}{l}\text { Step } 2 \text { - Moderating } \\
\text { Variable (CoI) }\end{array}$ & & & .385 & .825 & -.909 & -1.720 \\
\hline $\begin{array}{l}\text { Step } 3 \text { - Interaction } \\
\text { (DMIC x CoI) }\end{array}$ & & & & & 1.040 & 1.333 \\
\hline
\end{tabular}

Note: *Sig. at $p<.05$

It is concluded from the analysis above that Designing Modern Islamic Curriculum (DMIC) will produce high Santris' Academic Achievements (SAA). Besides that, DMIC will generate Surplus of Fund from Operation (SFO) and attract a large percentage of Santris from Non-Local Areas (SNL). The other conclusion is: Capacity of Innovation (CoI) has moderated the relationships between DMIC and SAA: When CoI is high, DMIC will produce higher SAA.

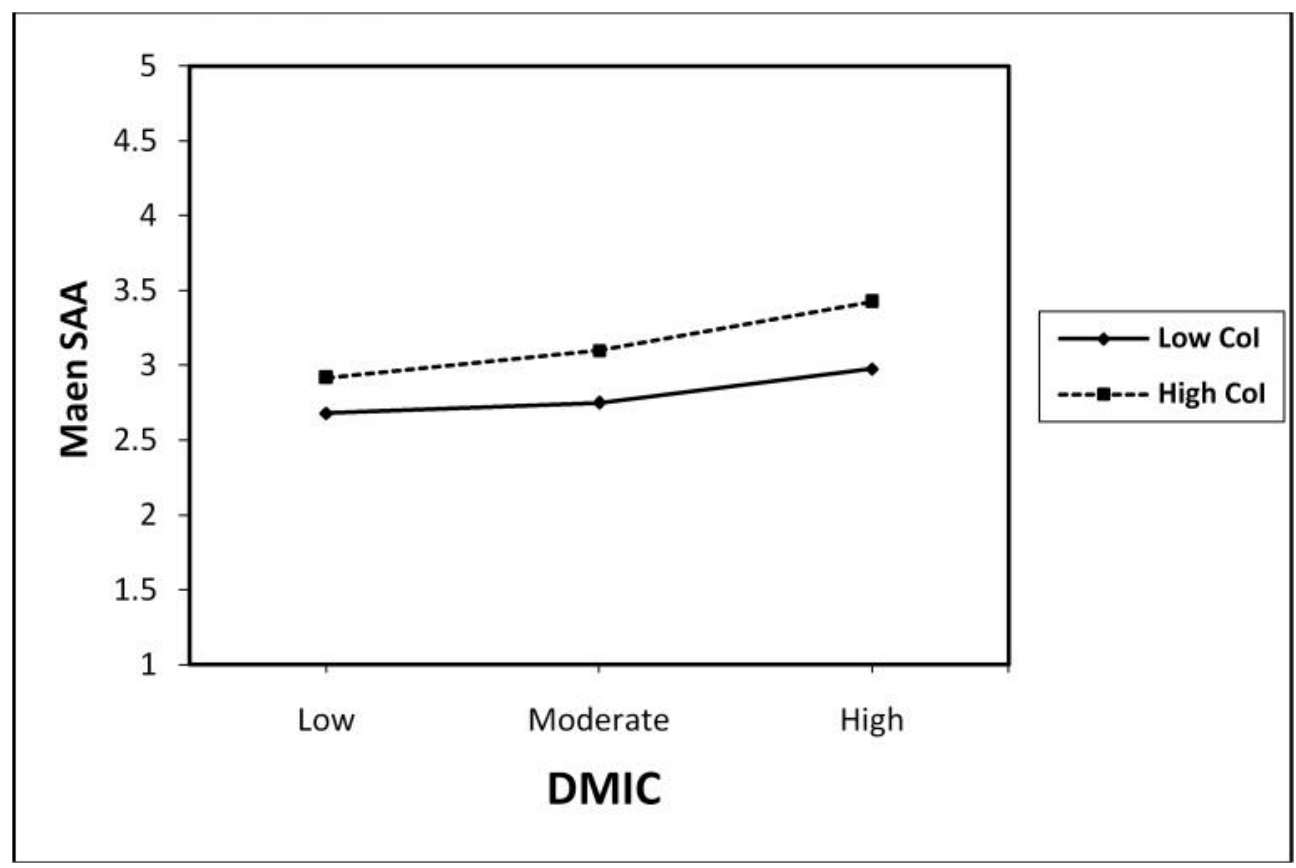

Figure 1: Interaction between Designing Modern Islamic Curriculum (DMIC) and Levels of Capacity of Innovation (CoI) for Santri's Academic Achievements (SAA) 
The figure above shows that the effect of Designing the Modern Islamic Curriculum (DMIC) on Santris' Academic Achievements (SAA), which is moderated by Capacity of Innovation (CoI). Levels of CoI have impacted the influence of DMIC on SAA: The positive effects of DMIC on SAA are lower both for low and high CoI is in the low to moderate level of DMIC, The positive effects of DMIC on SAA are higher both for low and high CoI is in the moderate to high level of DMIC, The positive effect of DMIC on SAA is in the low to moderate level of DMIC on high CoI is much higher than that of on low CoI.

There are several conditions that relate the highly innovative Pesantren to DMIC in order to produce higher SAA: The process of DMIC must be fully supported by the Kyai, as the top manager of the Pesantrens, All employees of the Pesantren, including Ustadzs and staffs, must have full commitment in supporting the process of DMIC, The Pesantren has to support the process of DMIC with the needed resources, such as: budget, tools, and human resources, The persons who are responsible for DMIC must have good capability in capturing and generating new ideas for innovation, both from internal and external environment.

\section{Conclusion}

The Pesantren has contributed much to the development of the Indonesian state, with many leaders in the Indonesian Government and private sector being alumni of Pesantren. One of them was Abdurrahman Wahid, the fourth President of Indonesia. However, in the the last few years because of their poor performances, a growing number of Pesantrens in North Sumatera has been closed.

This paper aims to investigate the problem with the Pesantren's poor performances in North Sumatera by elaborating a strategic activity: designing the curriculum which influences performances of the Pesantren. Therefore, this paper integrates Theory of SE and Contingency Theory. Theory of SE functions to explain phenomena of the Pesantren, which is arguably a form of Social Entrepreneurships (SEs), meanwhile Contingency theory is used as a basis for building the theoretical framework of this study.

Designing the curriculum is a process of selecting and organizing the formal and informal contents of teaching-learning program. The Pesantren must design its curriculum with Modern Islamic type properly in order to produce Santris' Academic Achievements (SAA), generate Surplus of Funds from Operation (SFO), and attract a large percentage of Santris from Non-Local Areas (SNL). However, only by designing its curriculum with the modern Islamic type is not sufficient enough to ensure the Pesantren's success. It must be supported by having high Capacity of Innovation (CoI) in order to produce better SAA.

With having strong independence as mentioned by Rahim (2011), the Pesantren actually has the opportunities to design its modern Islamic curriculum and educational models that it wants to implement freely. One of the opportunities is by developing its 
modern Islamic curriculum with specific core competencies that can differentiate it from the other education institutions.

From the findings of this paper, the Pesantren like the other forms of SE needs innovation in order to solve its problems better. This is in accordance with the opinion of Shaw and Carter (2007) and other scholars who agree that innovation is a key characteristic of SE.

\section{References}

Abu-Saifan, S. Social Entrepreneurship: Definition and Boundaries, Technology Innovation Management Review, Ed. February 2012.

Bornstein, D., \& Davis S. Social Entrepreneurship: What Everyone Needs to Know. Oxford, UK: University Press, 2010.

Brooks, C.A. Social Entrepreneurship a Modern Approach to Social Value Creation. New Jersey, USA: Prentice Hall, 2009.

Ebrashi, R. E. "Social Entrepreneurship Theory and Sustainable Social Impact," in Social Responsibility Journal, Vol. 9, No. 2.

Mastuhu. Dinamika Sistem Pendidikan Pesantren: Suatu Kajian tentang Unsur dan Nilai Sistem Pendidikan Pesantren. Jakarta: INIS, 1994.

Neely, A., and Hii, J. "The Innovative Capacity of Firms," in Nang Yan Business Journal, Vol. 1-1.

Nicholls, A. "The Legitimacy of Social Enterpreneurship: Reflexive Isomorphism in a PrePradigmatic Field," in Entrepreneurship Theory \& Practice, Vol. 34, 4, 2010.

Salarzehi, et al., "Waqf as a Social Entrepreneurship Model in Islam," in International Journal of Business and Management, Vol. 5, No. 7, July 2010.

Santos, F.M. "A Positive Theory of Social Entrepreneurship," in Journal of Business Ethics, Vol. 111, 2012.

Sundin, E. Entrepreneurship and Social Community Care. Journal of Enterprising Communities: People and Places in the Global Economy. n.p.p.: n.p., 2011.

Tapsell, P. and Woods, C. A Spiral of Innovation Framework for Social Entrepreneurship: Social Innovation at the Gernerational Divide in an Indigenous Contex, Emergence: Complexity \& Organization. n.p.p.: n.p., 2008.

Yunus, M. "Social Business Entrepreneurs are the Solution," in Nicholls A. (ed.), Social Entrepreneurship: New Models of Sustainable Social Change. Oxford: Oxford University Press, 2008.

Zahra, S.A. et al. "A Typology of Social Entrepreneurs: Motives, Search Processes and Ethical Challenges," in Journal of Business Venturing, 24. 